\title{
Aspects of Learning style and Labour market entry; an Explorative study
}

Citation for published version (APA):

Semeijn, J. H., \& van der Velden, R. K. W. (2002). Aspects of Learning style and Labour market entry; an Explorative study. In Tor A. Johannessen, Ansgar Pedersen, \& Kurt Petersen (Eds.), Educational Innovation in Economics and Business Vi, Teaching Today the Knowledge of Tomorrow (pp. 301-324). Kluwer Academic Publishers. https://doi.org/10.1007/978-94-017-1390-0_20

Document status and date:

Published: 01/01/2002

DOI:

10.1007/978-94-017-1390-0_20

Document Version:

Publisher's PDF, also known as Version of record

\section{Please check the document version of this publication:}

- A submitted manuscript is the version of the article upon submission and before peer-review. There can be important differences between the submitted version and the official published version of record.

People interested in the research are advised to contact the author for the final version of the publication, or visit the DOI to the publisher's website.

- The final author version and the galley proof are versions of the publication after peer review.

- The final published version features the final layout of the paper including the volume, issue and page numbers.

Link to publication

\footnotetext{
General rights rights.

- You may freely distribute the URL identifying the publication in the public portal. please follow below link for the End User Agreement:

www.umlib.nl/taverne-license

Take down policy

If you believe that this document breaches copyright please contact us at:

repository@maastrichtuniversity.nl

providing details and we will investigate your claim.
}

Copyright and moral rights for the publications made accessible in the public portal are retained by the authors and/or other copyright owners and it is a condition of accessing publications that users recognise and abide by the legal requirements associated with these

- Users may download and print one copy of any publication from the public portal for the purpose of private study or research.

- You may not further distribute the material or use it for any profit-making activity or commercial gain

If the publication is distributed under the terms of Article $25 \mathrm{fa}$ of the Dutch Copyright Act, indicated by the "Taverne" license above, 


\section{Aspects of Learning Style and Labour Market Entry: an Explorative Study}

Judith H. Semeijn \& Rolf van der Velden

Research Centre for Education and the Labour Market (ROA), Maastricht University, Maastricht, the Netherlands

\section{INTRODUCTION}

Recent demands for people at the workplace are described by modern concepts like flexibility and ability to learn. The capacity of employees to adapt to new skill requirements that result from technological developments and global market dynamics is especially stressed (IRDAC, 1990; WRR, 1995; European Commission, 1996). This implies that important concepts under consideration for research into what makes people successful in labour market functioning are related to learning behavior. In order to become and stay employable, worker's capacity for life-long learning becomes crucial.

In labour market research, educational and skill requirements are considered to be of great importance for successful labour market functioning. However, despite this importance, sociologists and economists have very much considered the educational process as a black box. At best, education has been measured in number of years of education followed, or in terms of educational outcomes by grades, but the actual content of education or learning processes has been left to the domain of educational research. Educational research in turn has neglected the actual outcomes of education in terms of the effect on successful labour market entry and functioning. This research field, however, acknowledged the importance of individual differences in learning for learning outcomes. Already since the sixties and seventies the concept of "learning style" was used. Learning style refers to a set of individual characteristics which are relevant for individual differences i.e. preferences in the learning process (Biggs, 1993). It may be conceived as a relative stable trait of people. This stability stresses the question to what 
extent learning behavior can be developed or changed. However, since growing emphasis is put on the importance of individual skills and differences for labour market functioning (Nijhof, 1997), the existing concept and measurement of "learning style" from within the educational context may be valuable for analyzing differences in labour market functioning. Not only learning outcomes may be affected by differences in learning behavior or preferences, but labour market outcomes as well. And since learning continues after entering the labour market, the concept of learning style may be important during the further stages of working life as well, possibly related to employability.

Interesting research questions in this respect are: To what extent does learning style predict successful labour market entry? Can learning stylle predict the kind of job people obtain within a certain range of possibilities, matching their preferences related to learning? Does learning style predict employability?

This paper will take a first step by exploring the predictive effect of students' learning style measured during education for labour market entry. Because learning style refers to "preferences" in behavior, both labour market success in quantitative terms and the allocation to different types of jobs will be considered. A sample of graduates in Economics of Maastricht University will be used. The research question we address is: To what extent does learning style predict labour market entry features of graduates?

\section{THEORETICAL BACKGROUND}

Traditional labour market research recognizes the importance of education for the labour market. There are mainly two hypotheses: in the human capital theory education is considered to enhance people's productivity directly (Becker, 1964). More education means in this view more productivity. In the screening hypothesis on the other hand, education is considered to reflect desired capacities for employers (Thurow, 1975). In this view people have productive value in tendency for employers, but the real productivity will be developed on the job. Study results traditionally reflect the educational outcomes that are of importance: study results are widely considered to be used as screening devices by employers. However, the emphasis is now put on more individual characteristics in selection practice. And the question rises what these characteristics are exactly and how to measure them.

General skills pertaining to cognitive abilities, personal characteristics and learning skills, are considered as key qualifications for people (e.g. Nijhof, 1997), but it remains unclear in most labour markét research how 
these concepts can be measured. Presland (1994) advocates the use of the learning style concept because of its relevance for continuous development during work. We think the educational concept of learning style has something to offer in this case, although the concept itself still lacks a clear theoretical framework (Rayner \& Riding, 1997).

Roughly two views have been developed in learning style research (Biggs, 1993); a narrow view, which emphasizes the cognitive information processing part of learning (for example Kolb, 1976; Kolb, 1984; Schmeck et al., 1977) and a broad view, which implicates several other aspects, in addition to the cognitive processing parts, like motivation and regulation preferences of individuals (for example Entwistle et al., 1979; Nuy, 1991; Vermunt, 1992). In this broad view, an individual's learning style consists of a particular combination of cognitive information processing, regulation aspects and motivational aspects. In general, distinctions in three or four different learning styles are well accepted, as more or less prototypes of learning style. However, the styles are estimated using various composite measurements, depending on the instruments used.

A distinction in three learning style types, that can be described as being reproductive, achievement oriented, and meaning oriented, is rather common though (Entwistle et al., 1979; Nuy, 1991). The meaning oriented style is considered the desirable one; people scoring high on its scales can be characterized by having a large intrinsic motivation, by being disciplined and using cognitive information processing techniques like trying to have an overview, to use concrete examples and elaborate study materials by personal experiences. All in all, the study material is handled to obtain "meaning". The reproductive style is in this way more aimed at trying to remember the material and the achievement style at trying to obtain good study results no matter what.

When considering one learning style as being desirable, the question rises to what extent the learning style can be developed or changed?

From educational research findings the answer seems to be "yes" to a certain extent; several factors affect learning style, such as teaching style (Borg \& Shapiro, 1996), kind of tasks (Tsang, 1993), and the educational system or context (Eklund-Myrskog, 1997; Nuy, 1991; Nuy \& Moust, 1990). Thus, it should be possible to manipulate students' learning behavior with the "right" tasks, the right teaching style and the right system. It depends on the perspective on "right" and "desirable". Research has been aimed frequently at the effects of learning style on learning outcomes (Crombach et al., 1975; Smit \& Van Os, 1985; Vermunt; 1992), but the relationship is not conclusive. Probably, the factors affecting learning style do play a role in this. Gijselaers et al (1989) studied the effect of learning style on study 
outcomes and concluded the educational system had affected students" learning style into an "undesirable" direction.

When learning style is considered rather stable, but on the other hand, can be developed to a certain extent as well, what are the consequences for predicting labour market entry features from learning style measured during education? In this case it seems important to analyze the predictive value of both study results and learning style at the same time to find out whether first of all there are any effects of learning style measured during education on labour market outcomes, and second whether these effects would be merely direct, or indirect, i.e. that the effects are mediated by study results. In the case the effect is independent from study results one could argue the learning style concept has much value for labour market research. When its effects would merely be indirect, meaning study results are stronger indicators for labour market entry features, the concept would not add much value for predicting labour market entry. However, when no effects for learning style could be found, whille for study results there could, we should doubt the use of this concept.

It may be possible that learning style is not valuable in predicting a more or less successful labour market entry, but that it regulates the allocation process on the labour market in a more qualitative manner. The question that arizes is whether people with different learning style characteristics end up in different jobs? One could argue that for example "grasping just the main line" during information processing would be positive for a manager, but negative for an accountant, although both graduated in economics. This relates to the matching perspective. In the research field of personnel selection and job analysis, all kinds of individual characteristics have been studied in relation to job characteristics, for example work related values (Judge \& Bretz, 1992), cognitive ability (Lancaster et al., 1994) and personality constructs (Raymark et al., 1997). Results show that people tend to choose those jobs that match their abilities, vocational interests and personality (Shrauger \& Osberg, 1981; Lancaster et al., 1994). The personal characteristics studied all seem to have a positive effect on job functioning and satisfaction when a match is established. Cognitive ability and specific personality characteristics are considered to be more related to the job, whereas work values are more related to the organization. Despite the argument of its relevance for the working environment (Hayes \& Allinson, 1997), the concept of learning style has not been used in this research field. However, it may be possible that the relative stable concept of learning style can tell us something about the kind of job a person chooses.

From different lines of research, learning style seems to potentially have an important effect on differences in labour market position and functioning. Therefore, in this paper, the predictive value of different learning style 
aspects will be explored with a sample of graduates in Economics of Maastricht University. The research question that will be addressed is:" To what extent do learning style aspects predict labour market entry features, when taking the traditional labour market research variables into account?

\section{DATA AND METHODOLOGY}

The data in this study consists of a sample of students of Economics of the Maastricht University, for whom data have been gathered in several subsequent waves. In 1986 and 1987 all first year students were asked to give information about their learning behavior (Gijselaers, 1989). Scales have been constructed to measure the different components of students' learning style, each scale consisting of 6 to 10 items. The items are Likerttype. The sum score on a scale is used to reflect the score of an individual for that scale. Most scales turned out to be very reliable with Alpha of .80 or more. The total range of reliability varied from .60 for globalism to .90 for fear of failure.

One and a half year after graduation, all students received a questionnaire relating to the process of labour market entry. These surveys are carried out on a regular basis by the Research Centre for Education and the Labour Market (Dutch shortcut: ROA) and studies are reported every year with cohorts of graduates of the Maastricht University (see Ramaekers, 19931996). For this analysis, data were used from the 1991 to 1995 waves. These waves comprise most of the first-year students who were in the original 1986 and 1987 learning style survey. The resulting sample consists of 156 graduates. Six indicators of labour market entry from the labour market survey are used as dependent variables. These indicators pertain to job chances, quality of work and type of job. The dependents are:

- Being employed at the date of the survey (approximately a year and a half after graduation, referring to job chances).

- Having a job within three months after graduation (referring to job chances).

- Having a permanent job (referring to both job chances and quality of work).

- Having a job for which an academic degree is required (quality of work).

- Gross monthly wages (quality of work).

- Having a managing, an accounting, or a research job (referring to kind of job).

Next to the indicators of labor market success, the particular job in which graduates end up is supposed to be related to the learning style. The 
classification of jobs into particular types is based on theoretical views used in job choice literature and classifications used in labor market research. The classification of jobs for this study will be dealt with in appendix 1 . The learning style data used in this paper relate to a number of different aspects. Table 1 presents an overview of the different scales that are used. The scales can be divided into aspects dealing with cognitive information processing or with motivational aspects. It is beyond the scope of this paper to explore their developmental and theoretical background. Rather, we will take their relevance as given and explore these aspects in predicting labor market entry features.

Table 1: Meaning of the scales of learning style as defined by Nuy (1991).

Scales
Cognitive information processing:
Holism

Holism

Globalism

Extendedness

Elaboration

Construction

Memorizing

Atomism

Motivational aspects:

Intrinsic motivation

Extrinsic motivation

Achiewement motivation

Fear of failure

\section{Description of scale content}

Student reacts easily to new study subjects by intuitive knowledge and broad associations; ability to grasp the main point in short time

Studying is limited to the most important points, working up to a rough view of the matter, skipping (possibly relevant) details Broad versus narrow scope in exploring study content; locating answers to study questions within a wider context; taking into account different perspectives to describe the subjject

Relating study content to pre-knowledge and own experience; looking for examples and applications

Active and critical incorporation of concepts and theories into a coherent and interconnected body of knowledge Learning by hart; concentrating on literal recall

Concentration on specific and isolated elements in the subject matter, which prevents reaching an overwiew

Interest in study content; challenged by questions and problems

Instrumental function of studying

Need to excel; high standards of achievement Avoidance of stress and uncertainty 
For the purpose of this study, relevant covariates were considered for their effect on labor market entry as well. By using administrative data for all students, the following covariates have been taken on board:

- Male (dummy);

- Age;

- Study length;

- Study field business administration, core subjects accounting \& finance (dummy);

- Study field business administration, core subjects organization \& marketing (dummy);

- Study field international management, core subjects accounting \& finance (dummy);

- Study field international management, core subjects organization \& marketing (dummy);

- Mean study results during the last two years of the graduate study program;

- Final thesis result; grade for the individual final study project.

Logistic and normal linear regression analyses will be applied with respect to the labor market indicators pertaining to job chances and quality of work for the motivational aspects and the following cognitive information processing aspects: Atomism, Elaboration, Memorizing and Construction.

Multinomial logistic regression analyses will be applied to the type of job graduates obtain with respect to the following cognitive information processing aspects: Holism, Globalism and Extendedness. The reason for including just these three cognitive information processing aspects is the following: when considering the meaning of the scales as described in table 1 , the authors interpreted these scales intuitively to be possibly positive for some jobs, but at the same time possibly negative for other jobs. However, the nature of this study is explorative and we therefore do not pretend to have some fundamented reason behind this choice. On the other hand, including all variables into the multinomial logistic regression analyses would not be informative, because of the large number of variables and the modest number of cases. In our opinion, for the other cognitive information processing scales, the different effects for different jobs would be less clear from their content meaning.

Analyses will be applied in a two-step model; in the first step the learning style aspects and covariates age, gender and study length are analyzed for their effect on labor market entry. In the second step, the more traditional labor market research variables are introduced into the model: study field and study results. In this way, the gross effect of learning style will be measured by the first-step model and the net effect in relation to study related independents by the second-step-model. 
Table 2a: Descriptive statistics of all variables.

\begin{tabular}{|c|c|c|c|}
\hline Variables & Mean & SD & $\mathrm{N}$ \\
\hline \multicolumn{4}{|l|}{ Indicators of Laboum Morket Success } \\
\hline (1) Being employed & 0.875 & 0.332 & 136 \\
\hline (2) Being unemployed less than three months & 0.740 & 0.440 & 150 \\
\hline (3) Having a permanent job & 0.558 & 0.499 & 113 \\
\hline (4) Hawing a job requining an academic degree & 0.607 & 0.491 & 117 \\
\hline (5) Gross monthly wages (log) & 8.190 & 0.300 & 112 \\
\hline \multicolumn{4}{|l|}{ Job Categary } \\
\hline (6) Managers & 0.350 & 0.480 & 71 \\
\hline (7) Scientists & 0.300 & 0.460 & 71 \\
\hline (8) Accountants & 0.320 & 0.470 & 71 \\
\hline (9) Other Jobs & 0.028 & 0.170 & 71 \\
\hline \multicolumn{4}{|l|}{ Learning Style } \\
\hline Atomism & 9.830 & 4.080 & 156 \\
\hline Construction & 19.050 & 4.550 & 156 \\
\hline Ellaboration & 18.420 & 3.090 & 156 \\
\hline Memorizing & 8.190 & 3.920 & 156 \\
\hline Holism & 17.090 & 3.930 & 156 \\
\hline Globalism & 8.880 & 3.180 & 156 \\
\hline Extendedness & 11.350 & 3.590 & 156 \\
\hline Intrinsic moti vation & 15.330 & 3.620 & 156 \\
\hline Extrinsic motivation & 13.010 & 3.950 & 156 \\
\hline Achiewement motivation & 12.760 & 4.070 & 156 \\
\hline Fear of failure & 8.050 & 5.120 & 156 \\
\hline \multicolumn{4}{|l|}{ Control Variables } \\
\hline Male & 0.720 & 0.450 & 156 \\
\hline Age & 25.776 & 1.509 & 156 \\
\hline Study length & 66.200 & 11.060 & 156 \\
\hline \multicolumn{4}{|l|}{ Study Field } \\
\hline Business Adm, accownting/finance & 0.310 & 0.460 & 154 \\
\hline Business Adm., organization/marketing & 0.300 & 0.460 & 154 \\
\hline Intern. Man., acc/fin./general economics & 0.097 & 0.300 & 155 \\
\hline Intern. Man., organization/marketing & 0.130 & 0.340 & 155 \\
\hline Othen Study Fields (reference) & 0.157 & 0.365 & 1.53 \\
\hline \multicolumn{4}{|l|}{ Study Results } \\
\hline Mean study results & 7.110 & 0.448 & 156 \\
\hline Final thesis result & 7.342 & 0.856 & $\mathbb{1 5 5}$ \\
\hline
\end{tabular}


Table $2 b$ : Pearson's correlations between independent and dependent wariables.

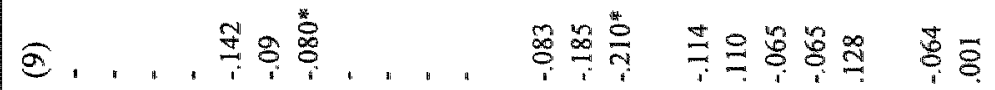

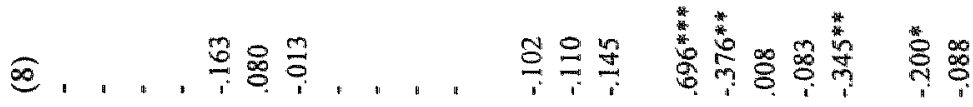

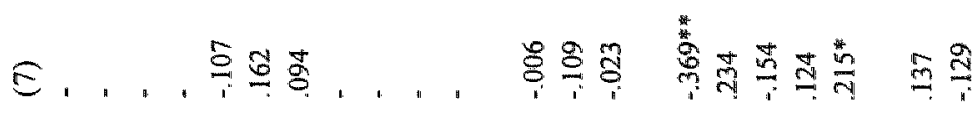

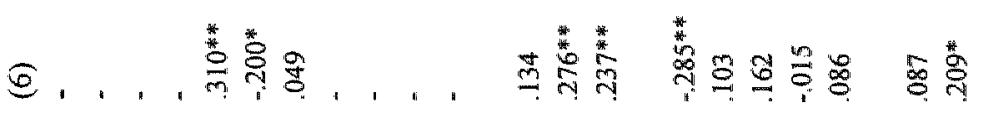

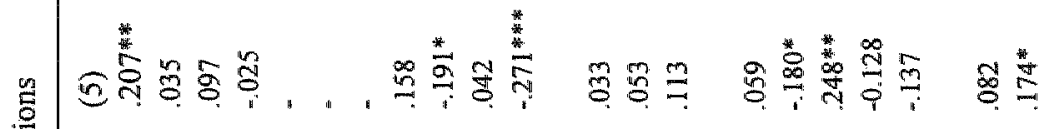

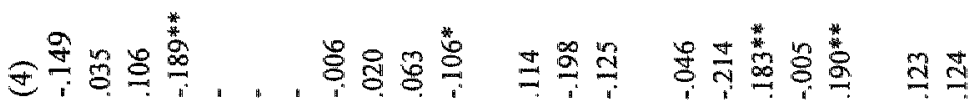

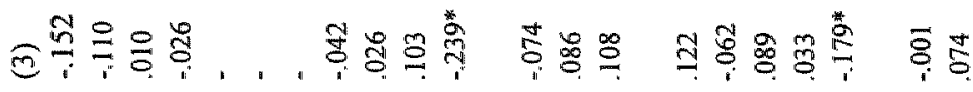

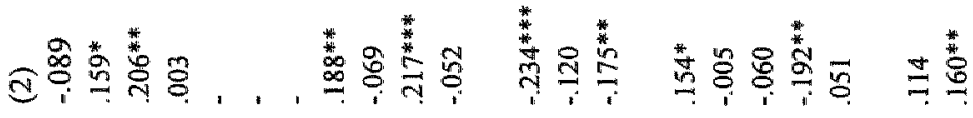

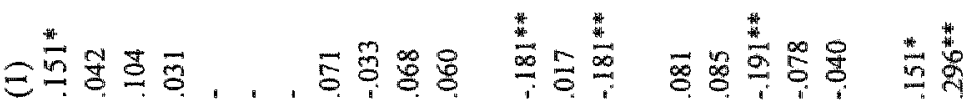

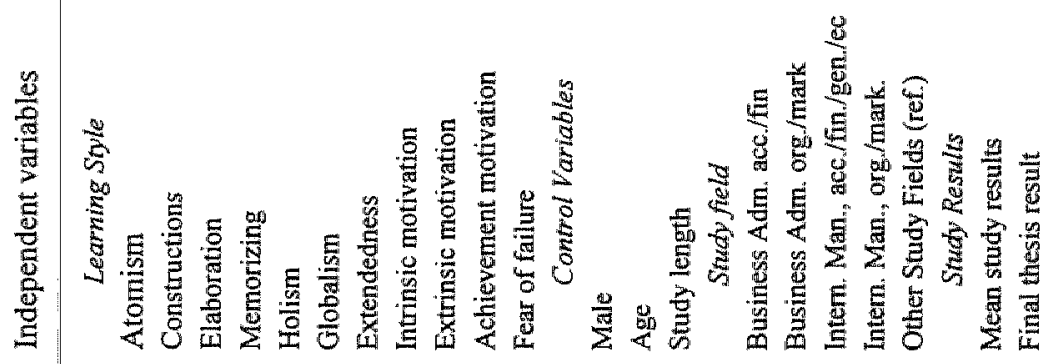


4. RESULTS

\subsection{General descriptive statistics}

First of all, descriptive results and plots were analyzed to screen for outliers and normality. For learning style aspects, no outliers are present and most interval variables show a near normal distribution. Table $2 \mathrm{a}$ presents the descriptives of all variables in the analyses, and Table $2 b$ the Pearson correlations of all variables with the dependents. Table $2 \mathrm{c}$ presents the Pearson correlations between learning style aspects and study results.

As can be seen from table $2 b$, the correlations between the learning style aspects on the one hand and study results on the other hand are rather limited. The only significant results point to negative effects of Extrinsic Motivation and Memorizing on mean study results. With normal linear regression analyses, the effects of learning style aspects on study results have been tested; the negative effect of Extrinsic Motivation can be confirmed for mean study results. No other scales sort any effect. For the final thesis variable, various scales have diverse effects, which are not easy to interpret. The only scale that seems to have an effect from the bivariate correlation, Extendedness, does not have any effect on final thesis result in the regression model.

So far, the learning style scales seem not to have a clear relationship with study results, which makes the possibility that learning style affects labor market entry through affecting study results less convincing.

Table 2c: Pearson's correlation between learning style aspects and covariates.

\begin{tabular}{lrr}
\hline Variables & \multicolumn{2}{c}{ Correlations } \\
Learming style aspects & Mean study results & Final thesils result \\
\hline Atomism & -0.053 & 0.084 \\
Construction & 0.010 & 0.013 \\
Elaboration & 0.027 & 0.085 \\
Memorizing & $-0.174^{* *}$ & 0.006 \\
Holism & 0.060 & 0.119 \\
Globalism & -0.091 & -0.081 \\
Extendedness & -0.020 & $-0.150 *$ \\
Intrinsic motivation & -0.014 & -0.005 \\
Extrinsic motivation & $-0.197 * *$ & -0.053 \\
Achievement motivation & 0.075 & 0.003 \\
Fear of failure & -0.005 & 0.050 \\
$*$ significant at $0.10, * *$ significant at 0.05 and *** significant at 0.01 & \\
\hline
\end{tabular}


Table 3: Regression estimates of the effects of learning style on having a job.

\begin{tabular}{|c|c|c|c|c|}
\hline & \multicolumn{2}{|c|}{ First-step model } & \multicolumn{2}{|c|}{ Second-step model } \\
\hline & $\mathrm{B}$ & s.e. & $\mathrm{B}$ & s.e. \\
\hline Constant & -2.438 & 6.698 & $-43.804 * * *$ & 15.883 \\
\hline \multicolumn{5}{|l|}{ Learning Style Aspects } \\
\hline Atomism & $0.222^{* *}$ & 0.105 & $0.358^{* *}$ & 0.156 \\
\hline Construction & -0.034 & 0.092 & -0.059 & 0.125 \\
\hline Elaborism & 0.147 & 0.134 & -0.028 & 0.241 \\
\hline Memorizing & -0.116 & 0.087 & -0.159 & 0.119 \\
\hline Intrinsic Motivation & -0.062 & 0.128 & 0.132 & 0.167 \\
\hline Extrinsic Motivation & -0.109 & 0.094 & -0.137 & 0.151 \\
\hline Achievement Motivation & 0.062 & 0.087 & 0.044 & 0.136 \\
\hline Fear of Failure & -0.048 & 0.069 & -0.134 & 0.101 \\
\hline \multicolumn{5}{|l|}{ Control Variables } \\
\hline Male & $-1.884 *$ & 1.103 & $-2.884 *$ & 1.494 \\
\hline Age & 0.447 & 0.310 & $1.208^{* * *}$ & 0.525 \\
\hline Study Length & $-0.096 * *$ & 0.038 & $-0.151^{* *}$ & 0.068 \\
\hline \multicolumn{5}{|l|}{ Study Field } \\
\hline Business Adm., acc./fin. & - & - & $2.851^{*}$ & 1.458 \\
\hline Business Adm., org/mark. & - & - & 1.572 & 1.350 \\
\hline \multicolumn{5}{|l|}{ Internat.Man., acc./fin./ } \\
\hline Gen.econ. & - & - & -1.639 & 1.421 \\
\hline Internat.Man ${ }_{\text {, }}$ org,/mark. & - & - & 0.075 & 1.223 \\
\hline \multicolumn{5}{|l|}{ Study Results } \\
\hline Mean Study Results & - & - & $2.069 *$ & 1.122 \\
\hline Final Thesis Result & - & - & $1.771^{* * * * *}$ & 0.641 \\
\hline \multicolumn{5}{|l|}{ Model Statistics } \\
\hline Number of cases (n) & & 136 & & 133 \\
\hline Model chi-square & & 19.573 & & 43.625 \\
\hline Df & & 11 & & 17 \\
\hline $\mathrm{P}$ & & 0.052 & & 0.000 \\
\hline $\mathrm{R}_{\mathrm{L}}^{2}$ & & 0.191 & & 0.806 \\
\hline
\end{tabular}

* significant at $0.10, * *$ significant at 0.05 and *** significant at 0.01 .

\subsection{Regression results for labor market entry chances}

Table 3 presents the results of the logistic regression analysis on the first dependent variable, related to job chances: being employed at the date of the survey. It appears that both models (first- and second-step model) differ significantly from the base model, in which only a constant is included. The learning style aspect Atomism has both in the first and the second-step model a significant positive effect on the odds of being employed a year and a half after graduation. To be precise, a one unit increase in the score on the Atomism scale is related to a multiplicative change in the odds of being employed of 1.25 and 1.43 respectively, which means changes up to $40 \%$. The finding of Atomism being positive related to being employed, is not 
intuitively clear. Taking the meaning of this cognitive aspect into account (table 1) the effect may be caused by searching behavior in which every vacant job is possibly interesting, ending up in many applications for vacant jobs and (therefore) a larger chance of success. For all other learning style aspects, no effects are found. Study results appear to have strong positive effects on the chance of having a job. And for the control variables, the larger the study length, the more detrimental it is for the chances of having a job, a year and a half after graduation. Men seem to have more difficulties in finding a job than women, and age appears to have a positive effect, allthough only in the second model. Finally, studying Business Administration, subjects accounting and finance, has a positive effect on the odds of having a job. Table 4 presents the results of the logistic regression on having a job within three months, the next variable related to job chances.

Table 4: Regression estimates of learning style on having a job within three months.

\begin{tabular}{|c|c|c|c|c|}
\hline & \multicolumn{2}{|c|}{ First-step model } & \multicolumn{2}{|c|}{ Second-step model } \\
\hline & $\mathrm{B}$ & s.e. & $\mathrm{B}$ & s.e. \\
\hline Constant & 6.929 & 4.233 & -0.091 & 7.305 \\
\hline \multicolumn{5}{|l|}{ Learning Style Aspects } \\
\hline Atomism & -0.052 & 0.067 & -0.045 & 0.073 \\
\hline Construction & -0.039 & 0.071 & -0.030 & 0.077 \\
\hline Elaborism & 0.081 & 0.099 & 0.004 & 0.113 \\
\hline Memorizing & -0.005 & 0.058 & -0.020 & 0.065 \\
\hline Intrinsic Motivation & 0.078 & 0.090 & 0.143 & 0.097 \\
\hline Extrinsic Motivation & 0.005 & 0.064 & 0.055 & 0.075 \\
\hline Achievement Motivation & $0.118^{*}$ & 0.062 & $0.151^{* *}$ & 0.073 \\
\hline Fear of Failure & -0.081 & 0.052 & $-0.118^{* *}$ & 0.059 \\
\hline \multicolumn{5}{|l|}{ Control Variables } \\
\hline Malle & $-1.645^{* *}$ & 0.627 & $-2113 * *$ & 0.695 \\
\hline Age & -0.167 & 0.160 & -0.149 & 0.182 \\
\hline Study Length & $-0.036^{*}$ & 0.021 & $-0,021$ & 0.023 \\
\hline \multicolumn{5}{|l|}{ Study Field } \\
\hline Business Adm., acc/fin. & - & - & 0.552 & 0.822 \\
\hline Business Adm., org/mark. & - & - & -0.869 & 0.756 \\
\hline \multicolumn{5}{|l|}{ Gen.econ. } \\
\hline \multicolumn{3}{|l|}{ Study Results } & $-1.576^{*}$ & 0.869 \\
\hline Mean Study Results & - & - & 0.550 & 0.600 \\
\hline Final Thesis Result & - & - & 0.287 & 0.276 \\
\hline \multicolumn{5}{|l|}{ Model Statistics } \\
\hline Number of cases (n) & & 150 & & 147 \\
\hline Model chi-square & & 28.194 & & 39.737 \\
\hline Df & & 11 & & 17 \\
\hline $\mathrm{P}$ & & 0.003 & & 0.00 \\
\hline$R^{2}$ & & 0.164 & & 0.237 \\
\hline
\end{tabular}

significant at $0.10, * *$ significant at 0.05 and *** significant at 0.01 
Table 5: Regression estimates of the effects of learning style on having tenure.

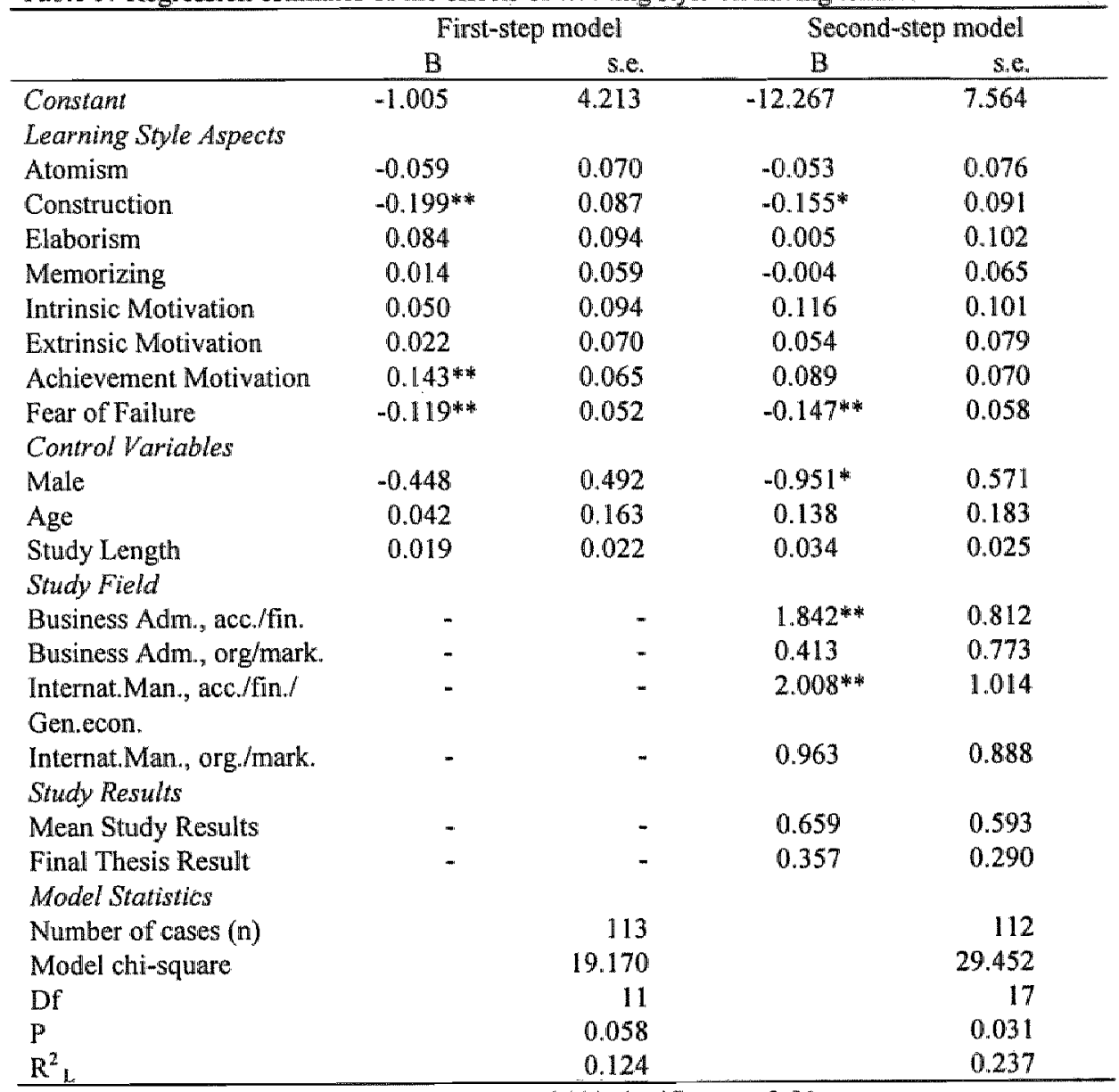

* significant at $0.10 * *$ significant at 0.05 and *** significant at 0.01

Table 5 presents the results with respect to the last indicator of labor market chances: having tenure. The results are obtained with logistic regression analyses again. Both the first- and the second-step modell differ significantly from the base model. The most striking result is the negative effect of Construction with regard to its meaning. This effect could be explained by the fact that most of the academic research jobs are on a temporary basis. The negative effect of Fear of Failure is more in line with our expectations, taking the content meaning of the scale into account. Achievement Motivation shows a positive effect on this labour market indicator. And being a male seems to be detrimental again. Study field variables in the second model do lead to large differences in the odlds of having tenure. Studying Business Administration, subjects accounting and/or 
finance, or studying International Management with the same subjects, leads to a far larger chance of having tenure, than do the other study programs. Study results, finally, do not show any effect on this labour market indicator.

\subsection{Regression results for labour market quality}

The next two variables tested in this study pertain to the quality of work. Table 6 presents the results of the effects on having an academic job, the first of these two variables.

Table 6: Regression estimates of the effects of learning style on having an academic job.

\begin{tabular}{|c|c|c|c|c|}
\hline & \multicolumn{2}{|c|}{ First-step model } & \multicolumn{2}{|c|}{ Second-step model } \\
\hline & $\mathrm{B}$ & s.e. & $\mathrm{B}$ & s.e. \\
\hline Constant & $10.421^{* * *}$ & 4.080 & 11.852 & 7.522 \\
\hline \multicolumn{5}{|l|}{ Learning Style Aspects } \\
\hline Atomism & -0.010 & 0.066 & -0.021 & 0.071 \\
\hline Construction & -0.078 & 0.079 & -0.137 & 0.087 \\
\hline Elaborism & 0.139 & 0.091 & $0.182^{*}$ & 0.099 \\
\hline Memorizing & $-0.125^{*}$ & 0.060 & -0.096 & 0.067 \\
\hline Intrinsic Motivation & 0.028 & 0.093 & 0.004 & 0.099 \\
\hline Extrinsic Motivation & 0.019 & 0.069 & 0.013 & 0.074 \\
\hline Achievement Motivation & 0.050 & 0.062 & 0.068 & 0.069 \\
\hline Fear of Failure & -0.047 & 0.052 & -0.040 & 0.054 \\
\hline \multicolumn{5}{|l|}{ Control Variables } \\
\hline Male & 0.685 & 0.489 & 0.559 & 0.541 \\
\hline Age & $-0.436 * * *$ & 0.157 & $-0.409 * *$ & 0.172 \\
\hline Study Length & -0.001 & 0.022 & 0.010 & 0.025 \\
\hline \multicolumn{5}{|l|}{ Study Field } \\
\hline Business Adm., acc./fĩn. & - & - & $-1.469 *$ & 0.850 \\
\hline Business Adm., org/mark & - & - & $-1.727^{* *}$ & 0.845 \\
\hline Internat.Man., acc./fin./ & - & - & 0.253 & 1.314 \\
\hline \multicolumn{5}{|l|}{ Gen.econ. } \\
\hline Internat.Man., org/mark. & - & - & -1.243 & 0.939 \\
\hline \multicolumn{5}{|l|}{ Study Results } \\
\hline Mean Study Results & $=$ & - & -0.4 .02 & 0.597 \\
\hline Final Thesis Result & - & - & 0.227 & 0.276 \\
\hline \multicolumn{5}{|l|}{ Model Statistics } \\
\hline Number of cases (n) & & 117 & & 115 \\
\hline Model chi-square & & 18.327 & & 27.302 \\
\hline Df & & 11 & & 17 \\
\hline $\mathrm{P}$ & & 0.074 & & 0.054 \\
\hline $\mathrm{R}^{2} \mathrm{~L}$ & & 0.117 & & 0.214 \\
\hline
\end{tabular}

* significant at $0.10, * *$ significant at 0.05 and ${ }^{* * *}$ significant at 0.01

Both models only differ significantly at the 0.1 significance level from the base model. Memorizing appears to have a negative effect on having an 
academic job. In the second-step model, Elaborism shows a positive effect. A negative effect of age is present in both models. This effect of age seems rather surprising, but is possibly caused by graduates who finished a study at higher vocational education before entering university. These graduates are in general older and more often inclined to look for a job at higher vocational level. Study fields within the Business Administration course seem to have detrimental effects on this labour market indicator. Study resullts, finally, appear to have no effects on the odds of having an academic job. The second variable related to the quality of work is (the log of) gross monthly wages, which will be tested in the next analysis. Graduates who are in a Ph. D. program were left out of this analysis, because their wages are fixed at a very low level, more comparable with a student loan than with regular wages. Table 7 presents the results.

Table 7: Regression estimates of the effects of learning style on gross monthly wages (log).

First-step model Second-step model

\begin{tabular}{|c|c|c|c|c|}
\hline & B & S.e. & B & \\
\hline Constant & $8.445^{* * * * *}$ & 0.049 & $7.624 * * *$ & 0.740 \\
\hline \multicolumn{5}{|l|}{ Learning Style Aspects } \\
\hline Atomism & -0.002 & 0.008 & -0.006 & 0.008 \\
\hline Construction & $-0.018^{*}$ & 0.009 & $-0.019 *$ * & 0.009 \\
\hline Elaborism & 0.001 & 0.011 & 0.001 & 0.011 \\
\hline Memorizing & 0.001 & 0.006 & 0.005 & 0.007 \\
\hline Intrinsic Motivation & $0.023^{* *}$ & 0.010 & $0.022 * *$ & 0.010 \\
\hline Extrinsic Motivation & -0.009 & 0.008 & -0.008 & 0.008 \\
\hline Achievement Motivation & 0.005 & 0.007 & 0.005 & 0.007 \\
\hline Fear of Failure & $-0.014^{* *}$ & 0.006 & $-0.012 * *$ & 0.006 \\
\hline \multicolumn{5}{|l|}{ Control Variables } \\
\hline Male & 0.029 & 0.054 & -0.009 & 0.056 \\
\hline Age & -0.001 & 0.017 & 0.010 & 0.018 \\
\hline Study Length & -0.001 & 0.002 & 0.001 & 0.002 \\
\hline \multicolumn{5}{|l|}{ Study Field } \\
\hline Business Adm., acc./fin. & - & - & 0.025 & 0.085 \\
\hline Business Adm., org/mark. & - & - & -0.106 & 0.083 \\
\hline Internat.Mant., acc./fin.// & - & - & 0.175 & 0.105 \\
\hline \multicolumn{5}{|l|}{ Gen.econ. } \\
\hline Internat.Man., org./mark. & - & - & -0.071 & 0.096 \\
\hline \multicolumn{5}{|l|}{ Study Results } \\
\hline Mean Study Results & - & - & 0.024 & 0.059 \\
\hline Final Thesis Result & - & - & 0.041 & 0.033 \\
\hline \multicolumn{5}{|l|}{ Model Statistics } \\
\hline Number of cases ( $n$ ) & & 105 & & 103 \\
\hline Model chi-square & & 0.065 & & 0.139 \\
\hline Df & & 1.662 & & 1.973 \\
\hline $\mathrm{P}$ & & 0.095 & & 0.022 \\
\hline
\end{tabular}

significant at $0.10, * *$ significant at 0.05 and **** significant at 0.01 
Only the second-step model differs significantly from the base model at the 0.05 level. Intrinsic Motivation shows a stable positive effect on wages. Fear of failure shows a negative effect on wages in both models. Construction shows a negative effect on wages as well, for which no clear argumentation can be given. No effects of study results and control variables are found.

\section{REGRESSION RESULTS FOR OBTAINING DIFFERENT JOBS}

To test the effect of the remaining three cognitive learning style aspects on labor market position, a different perspective is used. To see whether high scores on these different aspects would lead to (preference for) a different type of job, multinomial logistic regression is applied, again following the two step method of all other analyses, with exception of the inclusion of the variable study field. Study field is considered to be related to the type of job people obtain, because of relevance of the content. It is considered to be an important selection device for employers. In this way a match between study field and type of job is obvious. Table 8 a shows the relation between study field and type of job.

Table 8a: Cross tabulation of study field with job category.

\begin{tabular}{|c|c|c|c|c|}
\hline \multirow[b]{2}{*}{ Study field } & \multicolumn{4}{|c|}{ Job category } \\
\hline & $\begin{array}{c}\text { Managing } \\
\text { job }\end{array}$ & $\begin{array}{l}\text { Accounting } \\
\text { job }\end{array}$ & $\begin{array}{c}\text { Research } \\
\text { job }\end{array}$ & Total \\
\hline Business Adm, acc/finance & 3 & 17 & 1 & 21 \\
\hline Business Adm., org./marketing & 7 & 0 & 8 & 15 \\
\hline Int.Man., acc./fin./gen.econ. & 5 & 3 & 1 & 9 \\
\hline Int. Man,org./marketing & 3 & 2 & 4 & 9 \\
\hline Total & 18 & 22 & 14 & 54 \\
\hline
\end{tabular}

As can be seen from table 8a, accountants and other employees from the accountant job category are recruited almost exclusively from the study field accounting and finance. Researchers are in general recruited from the study fields organization and marketing. Only in the case of management jobs recruitment takes place from all possible study fields. Considering the high correlation between study field and type of job we expect that any effect of learning style on the type of job will be mediated through the choice of a specific study field. As we are interested merely in the gross effect of learning style on type of job, we decided to leave the study field variable out of the analyses altogether. Table $8 \mathrm{~b}$ presents the results of the analysis. 
Table $8 b$. Estimates of the effects of learning style on having an accounting job and a research job compared to having a managing job.

\begin{tabular}{|c|c|c|c|c|c|c|c|c|}
\hline & \multicolumn{4}{|c|}{ First-step model } & \multicolumn{4}{|c|}{ Second-step model } \\
\hline & \multicolumn{2}{|c|}{ accounting } & \multicolumn{2}{|l|}{ research } & \multicolumn{2}{|c|}{ accounting } & \multicolumn{2}{|l|}{ research } \\
\hline & estimate & s.e. & estimate & s.e. & estimate & s.e. & estimate & s.e. \\
\hline Constant & -9.957 & 6.724 & 0.217 & 6.446 & -12.050 & 10.193 & 14.725 & 9.835 \\
\hline$\frac{\text { Learning style }}{\text { aspects }}$ & & & & & & & & \\
\hline Holism & $0.186^{*}$ & 0.102 & 0.001 & 0.101 & 0.167 & 0.104 & 0.032 & 0.107 \\
\hline Globalism & $-0.216^{*} *$ & 0.105 & -0.065 & 0.100 & $-0.210 *$ & 0.107 & -0.063 & 0.105 \\
\hline Extendedness & -0.152 & 0.102 & -0.079 & 0.100 & $-0.184 *$ & 0.105 & -0.108 & 0.106 \\
\hline
\end{tabular}

Control

Variables:

\begin{tabular}{lllllllll}
\hline Male & -0.122 & 0.392 & 0.139 & 0.340 & -0.139 & 0.398 & 0.087 & 0.359 \\
A.ge & 0.384 & 0.275 & 0.130 & 0.273 & 0.380 & 0.276 & 0.025 & 0.277 \\
Study length & 0.008 & 0.036 & -0.029 & 0.035 & 0.012 & 0.038 & -0.059 & 0.041
\end{tabular}

$\underline{\text { Study Results }}$

Mean Study

Results

Final Thesis

Result

$-$

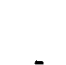


for entering an accounting job, in comparison with a manager's job, which is consistent with our expectation based on the content meaning of the scale; being accurate and precise is extremely important in accountant jobs. Globalism would not be convenient in such jobs.

For managing jobs, however, Globalism is (sometimes) inevitable and therefore much more useful. Extendedness shows a negative effect on entering an accounting job in comparison with a manager's job in the second model at the 0.1 level. Again, no effect for entering a research job is found. With respect to the covariates, no effects are found. Higher mean study results, however, seem to be detrimental for entering a research job in the second-step model. This seems rather surprising. Apparently, people with better study results do enter more managing and accounting jobs than research jobs.

To summarize the most important results of this paper, table 9 presents the significant outcomes for the learning style and study results variables.

As can be seen from table 9, learning style aspects affect both labour market entry success and type of job. Study results in fact only affect the indicator of having a job in general and obtaining a research job in this study. The effect of study results on having a job seems independent from the effect of the learning style aspect Atomism; the effect of Atomism does not disappear when the study related variables are introduced into the model. However, for the other dependents no profound effects of study results are found at all. The only learning style aspect that appeared to correlate with study results was Memorizing. However, for obtaining an academic job, Memorizing shows a stable negative effect, while study results do not show any effect at all.

Based on the content meaning of the scales, the effects of the motivational aspects of learning style seem rather straightforward, while the effects of the cognitive information processing aspects are far more difficult to explain. In the following and last section, the results of this explorative study will be considered for some conclusive remarks. 
Table 9: Results of the analyses.

\begin{tabular}{lllllll}
\multicolumn{2}{l}{ Dependents } & & & \\
\hline Being & Being & Hawing & Having & Gross & Accounting Research \\
employed & un- & tenure & an & monthly job & job \\
& $\begin{array}{l}\text { employed } \\
<3 \text { mths }\end{array}$ & & academic wages & category & category \\
& & & job & & & \\
& & & & & &
\end{tabular}

Independents

Learning

Style Aspects:

$\begin{array}{llllll}\text { Atomism } & \mathrm{X}+ & \mathrm{X} & \mathrm{X} & \mathrm{X} & \mathrm{X} \\ \text { Construction } & \mathrm{X} & \mathrm{X} & \mathrm{X}- & \mathrm{X} & \mathrm{X} \\ \text { Elaboration } & \mathrm{X} & \mathrm{X} & \mathrm{X} & \mathrm{X}+ & \mathrm{X} \\ \text { Memorizing } & \mathrm{X} & \mathrm{X} & \mathrm{X} & \mathrm{X}- & \mathrm{X}\end{array}$

Holism

Globalism

Extendedness

Intrinsic

motivation $\mathrm{X}$

Extrinsic

motivation $X$

Achievement

motivation $\mathrm{X}$

Fear of

faillure

$X \quad X-X-X \quad X-$

Study Results

Mean study

resullts

$\mathrm{X}+$

$X$

$\mathrm{X}$

X

$\mathrm{X}$

$\mathrm{X}$

$\mathrm{X}-$

Pinal thesis

result

$\mathrm{X}+$

X

X

$\mathrm{X}$

$\mathrm{X}$

$\mathrm{X}$

$\mathrm{X}$

$\mathrm{X}=$ the independent variable is included in the amalysis.

$t=$ effect of the independent variable is positive.

- = effect of the independent variable is negative.

\section{CONCLUSION}

In this explorative study the effects of learning style aspects on labour market entry success and type of job have been explored. The following conclusions can be drawn.

Aspects of cognitive information processing appear to affect both labour market chances and quality. Getting an academic job is the one indicator affected by only cognitive learning style aspects; a negative effect of Memorizing and a positive effect of Elaboration appeared. Since Memorizing correlates with study results within our sample, the effect of this aspect seems all the more important. Introducing the study results variables 
into the model did not diminish the effect of Memorizing, nor revealed an effect of study results variables themselves. For the other indicators of labour market success the effects of information processing aspects were less easy to interpret.

Motivation seems important for both job chances and quality of work. We found positive effects of Intrinsic and Achievement Motivation and negative effects of Fear of Failure, all reasonable to explain. Extrinsic Motivation shows no effect, which in fact means that it has no detrimental effect for labour market entry success.

With respect to the relation between learning style and type of job, the results were not conclusive. Globalism appears to have a negative effect on entering an accounting job in comparison with a managing job, for which we could give some reasonable explanation. On the other hand, we also found a positive effect of Holism and a negative effect of Extendedness on entering an accountant job, in comparison with a managing job. Both effects are not intuitively clear.

Study results only show an effect on the chance of being employed at the time of the survey. On the other indicators of labour market entry success no significant effects were found. This striking outcome seems to suggest that the effects of learning style aspects are more important for explaining labour market entry success than the more traditional labour market research variables.

However, careful choice of the instrument to measure learning style is warranted. Recent findings indicate relevant aspects of learning style as meta-cognition or self-regulating activities. These aspects seem to be very important in learning outcomes (Schouwenburg, 1996; Simons, 1997). Possibly, they will be important in labour market functioning as well. These aspects were not incorporated in the measurement of learning style used in this study.

Further, aspects of the learning style concept can be considered fundamental individual characteristics themselves, like personality traits and differences in brain functioning. The value added by using the learning style concept should therefore be clearly distinguished from these other concepts and possible measurements in further research.

Despite the limitations of the study, we think the results are promising. The findings indicate the importance of individual differences in cognitive information processing and motivational aspects for labour market research. However, we found only an effect on one of the indicators of labour market success. We think that linking the educational concept of learning style with labour market research reveals promising possibilities in extending both research fields. This is extremely important for both fields, now arriving at 
the point of integration, forced by the recent developments in the working environment.

\section{APPENDIX 1:}

\section{Job classification}

The classification of jobs used in this paper was designed to distinguish a limited number of meaningful categories. To make the categories of jobs as meaningful as possible, an approach is used, which combines ideas of Holland (1985), the division used by Spenner (1985), and the knowledge of job experts working at the Research Centre for Education and the Labour Market (Dutch shortcut ROA).

Based on the findings of Holland (1985) a distinction can be made in six personality types and their preferences for six different environments. Consequently, the work environment type can also be translated in terms of jobs or functions. Holland distinguishes the artistic, the realistic, the intellectual, the social, the entrepreneurial and the conventional type (of personality, environment, job). Being dominantly characterized by one type, persons, enviromments and jobs do also have characteristics of the other types, to a certain extent. In fact, the typology represents a framework: a hexagram. Persons, environments and jobs can be described by their position on this figure. The characteristics determine the position and some characteristics do relate easier than others, which means they are more consistent than others. In this hexagram there are three 'opposite' characteristics: conventional with artistic, realistic with social and intellectual with entrepreneurial. In formulating a classification of three different groups of jobs, it seems plausible to avoid to cluster these opposite, or inconsistent types. More related types are found more often empirically (Hogerheide, 1994).

In this way, it is defendable to cluster conventional with realistic, intellectual with artistic, and social with entrepreneurial, or conventional. with entrepreneurial, social with artistic and intellectual with realistic. In both situations these combinations do have the least distance, which means the largest consistency. However, the first classification appeals more to our approach with respect to differentiating jobs, than the second. Spenner (1985) is talking about "working with people, dlata, and things" in a study with respect to complexity in work. Working with people can be related to the entrepreneurial/social cluster, working with data to the intellectual/artistic cluster, and working with things to the conventional/realistic cluster. When using the other cluster possibillity of Holland's hexagram, the difficulties arise obviously in the intellectual/realistic cluster, where data and things mix. However, in this study a sample of graduates in economics is at hand, for whom possible jobs are by definition of a higher degree in complexity than just dividing them in working with people, things or data. But, when trying to classify the jobs, which are hold by our graduates in economics, we can defime jobs in which these categories could be reflected by accountants-jobs or computerjobs (things, conventional/realistic), research-jobs, or didactic jobs (data, intellectual/artistic), and managers-jobs or policy maker/advisory jobs (people, social/entrepreneurial). Thiis classification was double checked by a panel of job experts from ROA. 


\section{APPENDIX 2:}

\section{Detailed information on table $2 \mathrm{a}$}

Ass can be seen from table $2 a, 87.5 \%$ of the graduates were employed at the time of the labour market survey. The other $12.5 \%$ were unemployed. Some $75 \%$ of the graduates did find a job wery soon after graduation, and were unemployed less than three months. The other $25 \%$ were wnemployed for more than three months. Of all employed graduales more than a half (56\%) had tenure at the moment of the survey. Additionally, $60 \%$ of the graduates held a job for which an academic degree was required, whereas the other $40 \%$ were working in a job for which higher vocational education or less was sufficient. The mean gross monthly wages amounted to 3790 Dutch guilders. Of all academically employed graduates, $35 \%$ was working in a managing job, $30 \%$ in a research or teaching job, and another $32 \%$ in an accounting job. A small group of graduates of about $3 \%$ was employed in another kind of job, which wasn't defined by the former three categories. The largest part of our sample consists of men $(72 \%)$, and the mean age at the moment of the labour market survey was nearly 26 years. Most respondents graduated in Business Administration (61\%), with equal shares of the core subjects accounting/financing and organization/marketing. The other $39 \%$ consists of graduates in International Management (about $23 \%$ ), also divided over the two core subjects, and graduates in other subjects, which aren't defined further (the remaining $16 \%$ ). The mean study length of the graduates in our sample is approximately 66 months, or 5.5 years.

\section{REFERENCES}

Becker, G.S. (1994). Human Capital. New York: NBER.

$B$ iggs, J. (1993). What do inventories of student's learning processes really measure? A theoretical review and clarification. British Journal of Educational Psychology. Vol. 63, 319.

Borg, M.O., \& Shapiro, S.L. (1996). Personality type and student performance in principles of Economics. Journal of Economic Education, Vol. 27, 3-25.

Crombag, H.F., Gaff, J.F., \& Chang, T.M. (1975). Study behavior and academic performance. Tujdschrifl voor Onderwijsresearch, Vol. 1, 3-14.

Eklund-Myrskog, G. (1997). The influence of the educational context on student nurses" conceptions of learning and approaches to learning. British Journal of Educational Psychology, Vol. 67, 371-381.

Entwistle, N., Hanley, M., \& Hounsell, D. (1979). Identifying distinctive approaches to studying. Higher Education, Vol. 8, 365-380.

European Commission (1996). Teaching and Learning, Towards the Learning Society, White Paper, Luxembourg.

Gijselaers, W.H., Nuy, H., \& Mullink, J.P.M. (1989). Studie-aanpak en studierendement: deelrapport I van studies naar het propedeuserendement van de FdEWB. Vakgroep Onderwijsontwikkeling en Onderwijsresearch.

Hayes, J., \& Allison, C.W. (1997). Learming styles and training and development in work settings: lessons from educational research. Educational Psychology, Vol. 17, 1\&2, 185193.

Hogerheide, R.P. (1994)). De beroepskeuzetheorie van John L. Holland. In R.M.H. Spijkerman, A.J. Vincken, \& M.J. Weekenborg, (Eds.), Handboek Studie-en Beroepskeuzebegeleiding, Samsom, H.D., Willink, T. Alphen aan den Rijn. 
Holland, J.L. (1985). Making Vocational Choices: a theory of vocational personalities and work environments. Odessa, Florida: Psychological Assessment Resources.

Industrial Research and Development Advisory Committee (1991). Skill Shortages in Europe. Brussells.

Judge, T.A., \& Bretz, R.D. (1992). Effects of work values on job choice decisions. Journal of Applied Psychology, Vol 77 (3), 261-271.

Kolb, D.A. (1976). Learning Style Inventory, technical manual. New York, Englewood Cliffs: Prentice-Hall.

Kolb, D.A. (1984). Experiential Learning, experience as a source of learning and development. New York Englewood Cliffs: Prentice-Hall,.

Lancaster, S.J., Colarelli, S.M., King, D.W., \& Beehr, T.A. (1994). Job applicant similarity on cognitive ability, vocational interests, and personality characteristics: do similiar persons choose similiar jobs? Educational and' Psychological Measurement, Vol 54 (2), 299-316.

Nijhof, W.J. (1997). Qualifying for the future. In W.J. Nijhof, \& J.N. Streumer, (Eds.), Key Qualifications in Work and Education. Dordrecht: Kluwer Academic Press.

Nuy, H.P.J. (1991). Interactions of study orientation and student's appreciation of structure in their educational environment. Higher Education, Vol. 22, 267-274.

Nuy, H.P.J., \& Moust, J.H.C. (1990). Students and problem-based learning: how well do they fit in? Journal of Professional Legal Education, Vol. 8(2), 97-114.

Presland, J. (1994). Learning styles and CPD. Educational Psychology in Practice, Vol. 10 (3), $179-184$.

Ramaekers, G.W.M. (1996). WO-scanner economie 1995. Basismeting cohort '94, ROA-R1996/15, Research Centrum voor Onderwijs en Arbeidsmarkt, Maastricht.

Ramaekers, G.W.M. (1996). WO-scanner economie 1994. Basismeting cohort '93, ROA-R1996/1, Research Centrum voor Onderwijs en Arbeidsmarkt, Maastricht.

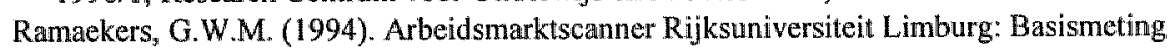
cohort '92, ROA-R-1994/7, Research Centrum voor Onderwijs en Arbeidsmarkt, Maastricht.

Ramaekers, G.W.M., \& Heijke, J.A.M. (1993). Arbeidsmarktscanner Rijksuniversiteit Limburg: Basismeting cohort "91, ROA-R-1993/13, Research Centrum voor Onderwijs en Arbeidsmarkt, Maastricht.

Ramaekers, G.W.M., \& Heijke, J.A.M. (1993). Arbeidsmarktscanner Rijksuniversiteit Limburg: Basismeting cohort '90, ROA-R-1993/1, Research Centrum voor Onderwijs en Arbeidsmarkt, Maastricht.

Raymark, P.H., Schmït, M.J., \& Guion, R.M. (1997). Identifying potentially useful personallity constructs for employee selection. Personnel Psychology, Vol. 50, 723-736.

Rayner, S., \& Riding, R. (1997). Towards a categorisation of cognitive styles and learning styles. Educational Psychology, Vol. 17, 5-27.

Schmeck, R.R., Ribick, R., \& Ramanaiah, N. (1977). Development of a self report inventory for assessing individual differences in learning processes. Applied Psychological Measurement, Vol.1, 413-431.

Schouwenburg, H.C. (1996). Een onderzoek naar leerstijlen. Tyjdschrift woor Onderwijsresearch, Vol. $2 l(2), 151-161$.

Shrauger, J.S., \& Osberg, T.M. (1981). The relative accuracy of self-predictions and judgement by others in psychological assessment. Psychological Bulletin, Vol. $90(2), 322$ 351.

Simons, P.R.J. (1997). Ontwilkeling van leercompetenties. Opleiding en Ontwikkeling, Vol. $6,17-20$. 
Smit, W., Van Os, W. (1985). Van studeergedrag naar studieresultat. In J.G. Lodewijks, \& P.J. Simons, (Eds.), Zelfstandig Leren (bijdragen aan de ORD 84). Lisse: Swets \& Zeitlinger.

Spenner, K.I. (1985). The upgrading and downgrading of occupations: issures, evidence, and implications for education. Rewiew of Educational Research, Wol. 55, 125-154.

Thurow, L.C. (1975). Generating Inequality. New York: Basic Books.

Tsang, N.M. (1993). Shifts of students' learning styles on a social work course. Social Work Education, Yol $12(1), 62-76$.

Vermunt, J.D.H.M. (1992). Leepstijlen en sturen wan leerprocessen in het hoger oxderwijs: natar een procesgerichte instructie in zelfstandig denken. Amsterdam/Lisse: Swets \& Zeitlinger.

Wetenschappelijke Raad woor het Regeringsbeleid (1995). Hoger onderwijs in fasen. Rapporten aan de Regering, 47, SDU, Den Haag. 